\title{
過去25年間の日本体育学会年次大会における 発表功みた身体運動に関する研究の主要傾向
}

\author{
飯塚 鉄 雄 (都立大学) \\ （昭和53年 4 月 30 日 受付）
}

\author{
The Major Trends of Research on Physical Activity in Japan \\ Viewd from the Reports Presented at the JSPE Annual \\ Conventions During Past 25 Years
}

Tetsuo Meshizuka*

抄録

日本体育学会㧍よび日本体力医学会（会員数それぞれ約 3,800 人：1,400人）に所属する会員の中で，それぞれ の機関誌である (1)体育学研究 (句体力科学および年次研究発表大会において口頭発表する者に, 研究者を求め ることができる.

およそ全会貝の12〜15パーセントの会員が毎年主要研究者あるいは研究協力者（共同研究者）としてこれらの 年次研究大会飞括いて発表する１977年度では，前者が的580，後者が130であった。

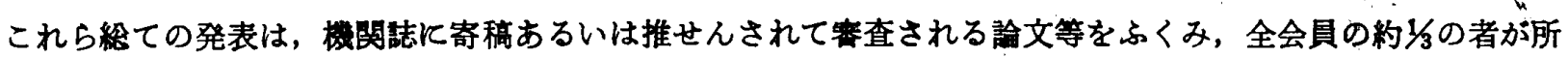
属する（日本体育学会の場合のみ）次の専門分科会の区分によって行なわれる.

(1)体育原理, (2)体育史，(3)体育社会学，(4)体育方法学，(5)体育管理学，(6)体育心理学，(7)発育発達学,

(8)キネシオロジー, (9)泪定評洒学, (10)体育生理学, (11)保健学

これら䌅ての発表が完全研究として刊行されることはなく, 先ず年次大会の組蟣委員会によって, 抄録として 網羅され，「大会号」として発表される．また，多くの発表はそれぞれの機関の「紀要」や学会支部あるいは， 専門分科会ごとにあ完全原稿として樂録される場合すある。

完全原稿として出版される研究の中で, どちらかと言えは, 自然科学系の論文の方が, 社会, 人文科学系のも のに比較して，より多く，また，口頭発表されたすのよりあ，より多くの論文がその他の関連誌に揭载される傾 向がみられる.

幸いにも「体育学」は日本に和ける学術体系の中であ正式に位置づけられ, 日本体育学会からす現在二人の会 貝を「日本学術会議」に送っている.しかし, 今後これらの諸研究全体がさらに実際の場面において, 特に一般 市民の健康と適性のために役立つようになることが望まれる。

(Tetsuo Meshizuka : The Major Trends of Research on Physical Activity in Japan Viewd from the Reports Presented at the JSPE Annual Conventions During Past 25 Years Jap. J. Phys. Educ., Vol. 23, No. 2, Sept., 1978, pp. 183 191)

\section{Intorduction}

The Japanese Society of Physical Education with its background of a quarter century

* Tokyo Metropolitan University, Physical Fitness Laboratory, Yagumo, Meguro-ku, Tokyo, Japan (152) 
history after the foundation was regarded rather appropriate to be reviewed for its re-starting into another quarter century to come. Since the society has been founded in order to promote the academic productivity of the members, the author intended to make a review only as to the research productivity through the reports presented at the annual conventions during past 25 years. For this purpose, the society decided to prepare three rseearch projects with some amount of research funds for each project, and Japanese Ministry of Education also agreed to provide the scientific research funds in addition to those for three years.

The interim reports on these projects were published in the professional periodical entitled, "Science of Physical Education" edited by the society")2).

This roport, however, aims to make review further in terms of the sizes of membership of the society during past 25 years in addition to those reported in our organ periodical; "Japanese Journal of Physical Education"3) in 1977. Two attempts of hierarchical classifications of the field of physical education so far were made by the society in the past without the consensus obtained at the general assembly, and one of these was utilized for the review while the other was used to classify the oral reports pressnted at the annual conventions in the program delivered to the participants.

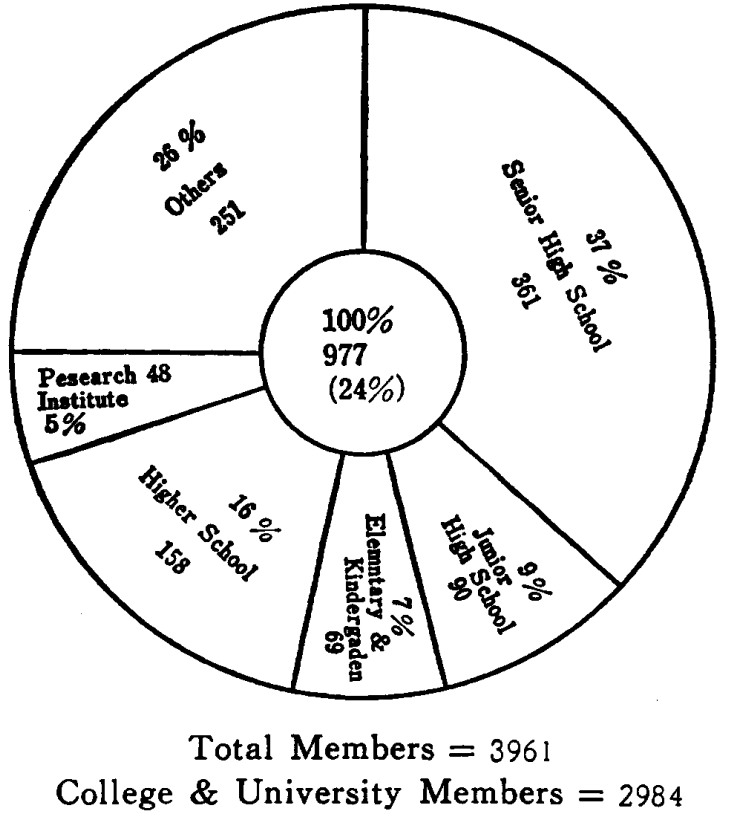

Fig. 1 The Classification of JSPE Members Other Than Those of College and University.

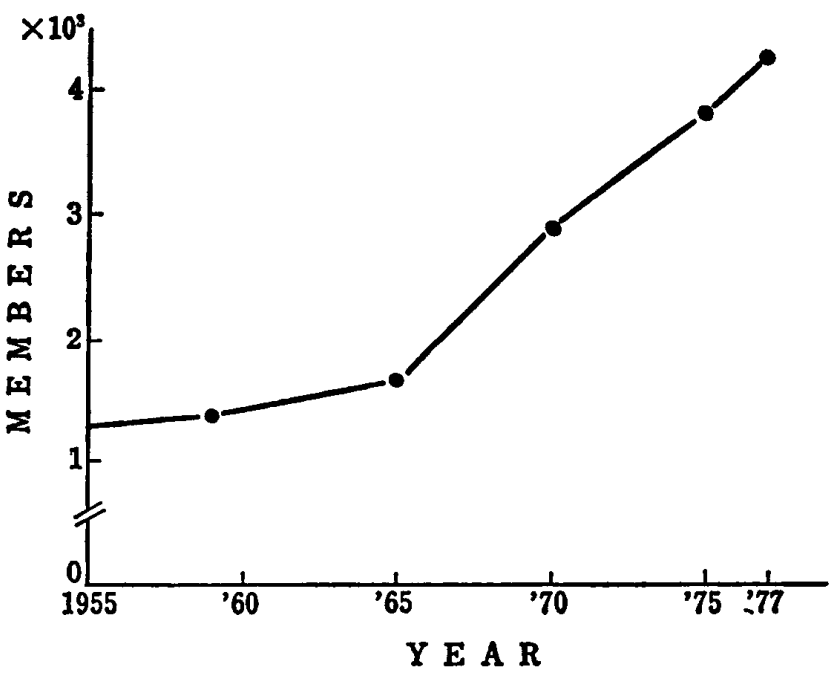

Fig. 2 The Increase of JSPE Membership : $1955-77$

There are about 50,000 school physical education teachers in Japan inclusive of those of college and universities, and the total number of the members of the society is exactly 3,961 as of April, 1978. Only 977 school teachers are affiliated to the society, and most membership of the society has been composed of college and university instructors in Japan. (Figure 1) At the same time, nearly 1,000 memebers are affiliated to Japanese Society of Physical Fitness and Sports Medicine. Since its foundation in 1950, the society trippled its membership from 1,300 to 4,000 today during past 25 years. (Figure 2) Beside these two 
professional organizations refered already, there are other three organizations of Physical educators; (1) All Japan College and University Physical Education Association, (2) Japanese Association of Physical Education for Girls and Women, and (3) Research Circle of School Health and Physical Education in Japan.

How many reseach reports have been presented in those professional groups is unknown, but it is quite sure that the number of the persons and reports are very limited. In this paper, the structure of the society relative to the research functions, the academic status of the field among other areas in Japan, and the themes and topics of the reports of the society by the members are reviewed together with the future prospect and tasks to be fulfilled.

\section{Structure of the Society}

Eleven research divisions as seen in Figure 4 have been functioning with their own membership, and the annual convention is usually programmed according to these divisions in relation to the research reports with the code numbers for each. There is another structure, which is administrative and these 31 district societies also organize their conventions sometimes coordinating several of them in a block. Two more research divisions are now under consideration : (1) Rehabilitation, and (2) Didactics of Physical ducation.

Out future problems in terms of the structure seem to be in (1) if we should include the school teachers in our society, (2) if we should change the title of the society into more like a science, or if we should seperate the members those who are research orientated from those who mainly apply the products in the actual situation, and (3) if we should make our efforts to let each research division to be an independent society under the society as the umblella.

\section{Academic Status of thd Field in Japan}

Our society sends today two members for the Science Council of Japan among 210 members elected by a nationwide voting by 200,000 qualified researchers divided into seven divisions : (1) Literature, history, philosophy, pedagogy-psychology-sociology, (2) Laws, (3) Economics, (4) Natural sciences, (5) Engeneering, (6) Agriculture, (7) Medicine. Physical education belongs to the first division, especially to pedagogy so far until a special research committee may be organized in future. In the seventh division, medicine, we succeeded to establish a special reserach committee called, "Physical-fitness Research Committee" in 1977 for which the author has been the general secretary. The academic status and the evaluation by other researchers are rather favorable to such an extent that they recognize ours more than that for "Education", perhaps because we named our field in Chinese letters without the word meaning anything of "Education". It is called something like, "Bodyculturing Science"; TAIIKU-GAKU in Japanese.

\section{Reserach Productivity of the Society}

Evaluating the academic productivity from the number of the oral reports presented 


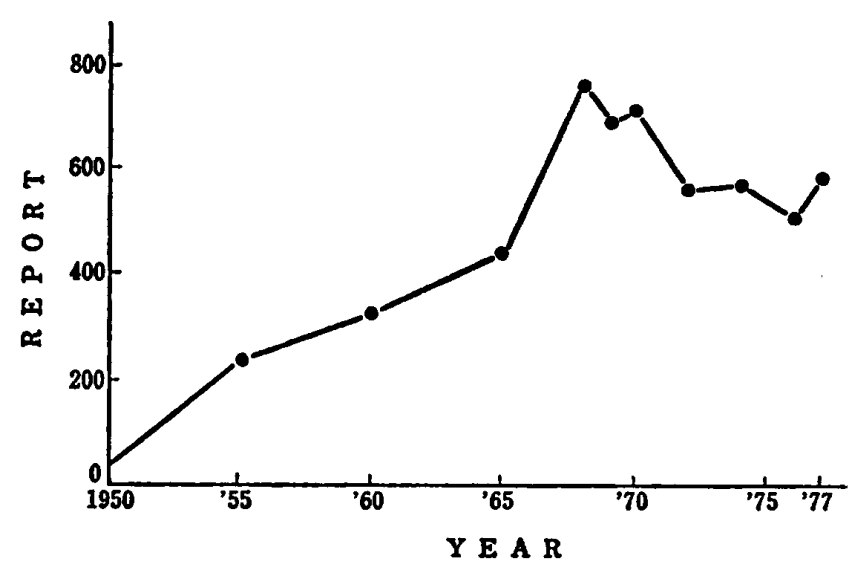

Fig. 3 Transition of the Numbers of Oral Reports Presented at the Annual Conventions : $1950 \sim 1977$ (JSPE)

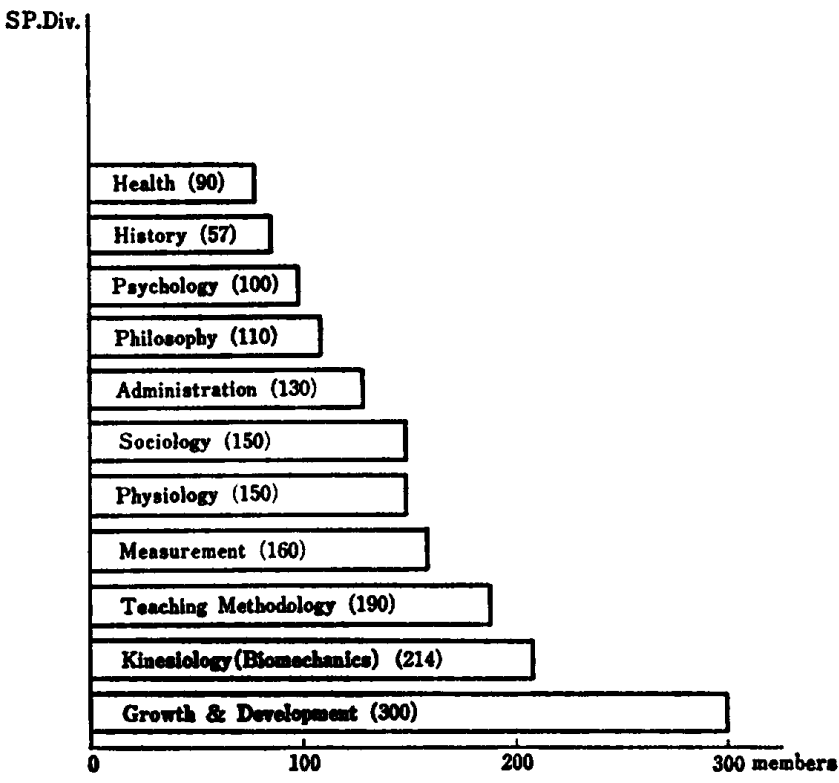

Fig. 4 Members of 11 Research Divisions of JSPE as of April, 1978.

at the annual conventions and the membership of the society, and also providing that these oral reports are usually presented by three members in average, approximately 50 per cent of the total members join in their reseach works with about 600 reports at each convention. (Figure 3) In other words, a half of the members of the society depend their academic tasks upon the other half always by listning and reading the printed materials and other informations available.

These numbers of oral reports appeares to coincide with the size of the membership of 11 reserach divisions of the society. (Figure 4) However, the decreaseing trend of the number of oral reports after around 1968 in comparison to the increase of the membership seems to due to the phenomenon that more members began presenting their papers also at such other societies as Japanese Society of Physical Fitness and Sports Medicine, Japanese Society of Ergonomics, and at some of the divisional conventions of their own.

Those eleven research divisions now functioning were organized in accordance with the by-laws of the society which states that more than 50 members can propose to organize the division in the society recognized at the general assembly. These divisions prepared during past 27 years may be classified into three categories: (1) social and human sciences, (2) natrual sciences, and (3) neutral and applied science. In the first category, philosophy, sociology and history may be included, and in the second category, physiology, kinesiology, psychology, and growth and development may be included. In the third category, health, measurement and evaluation, and teaching methodology may be included.

Despite some periodical fluctuations during past 25 years, there exist certain tendencies in the themes and topics preferred by the members in each of these 11 research divisions. Philosophical themes centered around the aims and objecitves and cultrual theories on sports, while sociology emphasized social functions of sports as a culture and structure of sports groups. (Figure 5) History on USA and west Europe and on post-war Japan has been marked, and sports programs and athletes were more interested in administration than other 


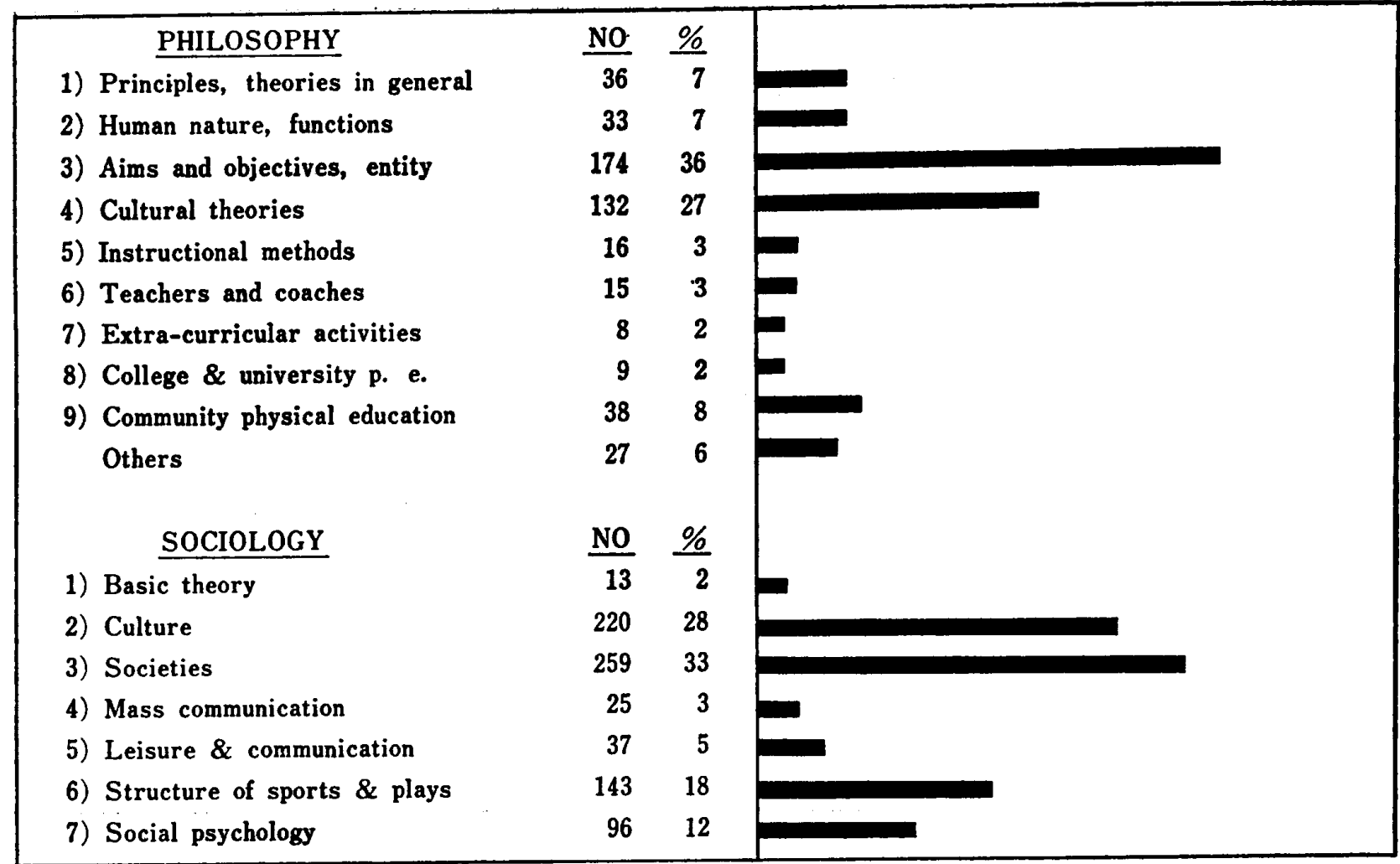

Fig. 5 Number and Ratio of the Reports at Convention During 1950-'74 in the areas of Philosophy and Sociology (JSPE).

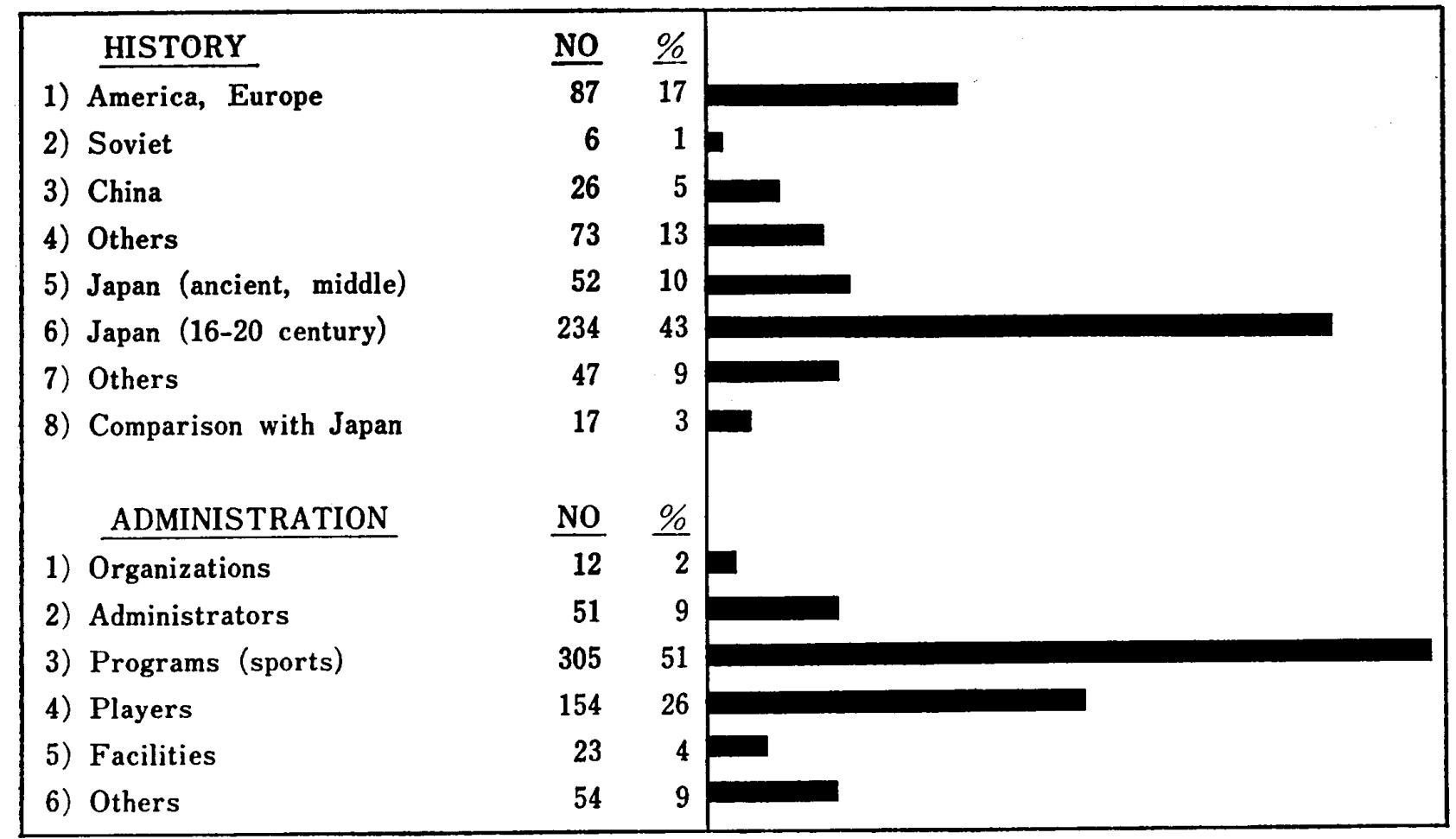

Fig. 6 Numbers and Ratios of Oral Reports Presented at the Annual Conventions : 1950 1974 (JSPE) 


PSYCHOLOGY
1) Growth \& development
2) Learning \& practice
3) Personality adgustment
4) Teaching or coaching
5) Expression (dance)
6) Psycho-physiological
7) Others

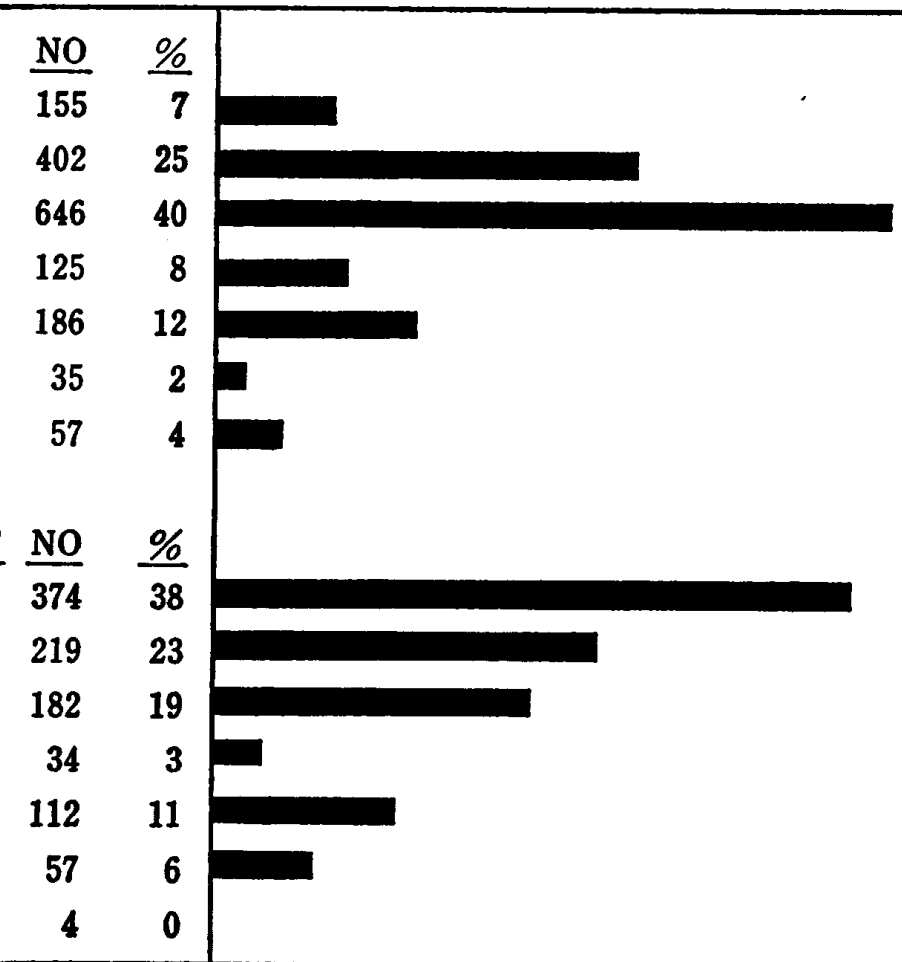

GROWTH \& DEVELOPMENT
1) Body size
2) Motor ability
3) Physical functions
4) Physical fitness
5) Adaptability
6) Psychological aspects
7) Others

Fig. 7 Numbers and Ratios of Oral Reports Presented at the Annual Conventions : 1950 1974 (JSPE)

\begin{tabular}{|lrr|l|}
\hline HEALTH EDUCATION & NO & $\%$ & \\
1) Exercise \& fatigue & 98 & 18 & \\
2) School health administration & 75 & 14 & \\
3) Health care, safety, sex ed. & 73 & 13 & \\
4) Health administ., communit. H.S. & 72 & 13 & \\
5) Physique, physical fitness & 47 & 9 & \\
6) Rehabilitation, health promot. & 40 & 7 & \\
7) Sport injury, first aid & 35 & 6 & \\
8) Sport medicine & 30 & 6 & \\
9) Health care in female exercise & 23 & 4 & \\
10) Environ. hygiene on sport equip. & 16 & 3 & \\
11) Others & 35 & 6 & \\
& & & \\
TEACHING METHODOLOGY & NO & $\%$ & \\
1) Gymnastics: educational & 23 & 3 & \\
2) Gymnastics: Olympic & 86 & 12 & \\
3) Athletics & 68 & 10 & \\
4) Ball games: basketbali & 141 & 20 & \\
5) Ball games: volleyball & 72 & 10 & \\
6) Ball games: others & 77 & 11 & \\
7) Swimming & 22 & 3 & \\
8) Combatives & 82 & 11 & \\
9) Dance & 89 & 12 & \\
10) Others & 57 & 8 & \\
\hline
\end{tabular}

Fig. 8 Nnmbers and Ratios of Oral Reports Presented at the Annual Conventions : 1950 1974 (JSPE) 


\begin{tabular}{|lrr|l|}
\hline BIOMECHANICS(BASIC) & NO & $\%$ & \\
1) Posture, center of gravity & 68 & 20 & \\
2) Physical fitness & 116 & 34 & \\
3) EMG studies & 33 & 10 & \\
4) Functions, traits & 61 & 18 & \\
5) Theories & 18 & 5 & \\
6) Measuring equipments & 30 & 9 & \\
7) Others & 17 & 5 & \\
& & & \\
BIOMECHANICS(APPLIED) & NO & $\%$ & \\
1) Athletics & 83 & 16 & \\
2) Aquatics & 33 & 6 & \\
3) Dance & 25 & 5 & \\
4) Ball games & 92 & 17 & \\
5) Combative sports & 69 & 13 & \\
6) Gymnastics & 82 & 15 & \\
7) Archery & 8 & 2 & \\
8) Ski \& skate & 44 & 8 & \\
6) Weight lifting & 2 & 0 & \\
7) Basic movements & 90 & 17 & \\
8) Others & 3 & 1 & \\
\hline
\end{tabular}

Fig. 9 Numbers and Ratios of Oral Reports Presented at the Annual Conventions : 1950 1974 (JSPE)

topics. (Figure 6) Personality adgustment through sports as the media attracted the interest of the members and next came the motor learning of physical activity in psychology, while physique, somatotype versus physical-fitness factors were liked by the members in growth and development. (Figure 7)

In health education, activity and fatigue, school health administration were marked, and ball games were studied more in teaching methodology. (Figure 8) In kinesiology or biomechanics, mechanical analyses of fundamental human body mevements were most popular in terms of each factors of physical fitness, while skill analyses were main topics of the study in measurement and evaluation with those of the traditional measurements on physique, and on over-all topics the reports were made in physiology. (Figure 10)

These tendencies seem reflecting those in other countries also in the world, and more emphasis has been placed on the effects of physical acitivities in general as the media of education and health and fitness maintenance after 15 to 22 years old at school into the life-long career of 70 and over. The research and investigation on the mass of people also has been redirected tnto that of each individual human being in order to clarify the mechanisms involoved in detatil. 


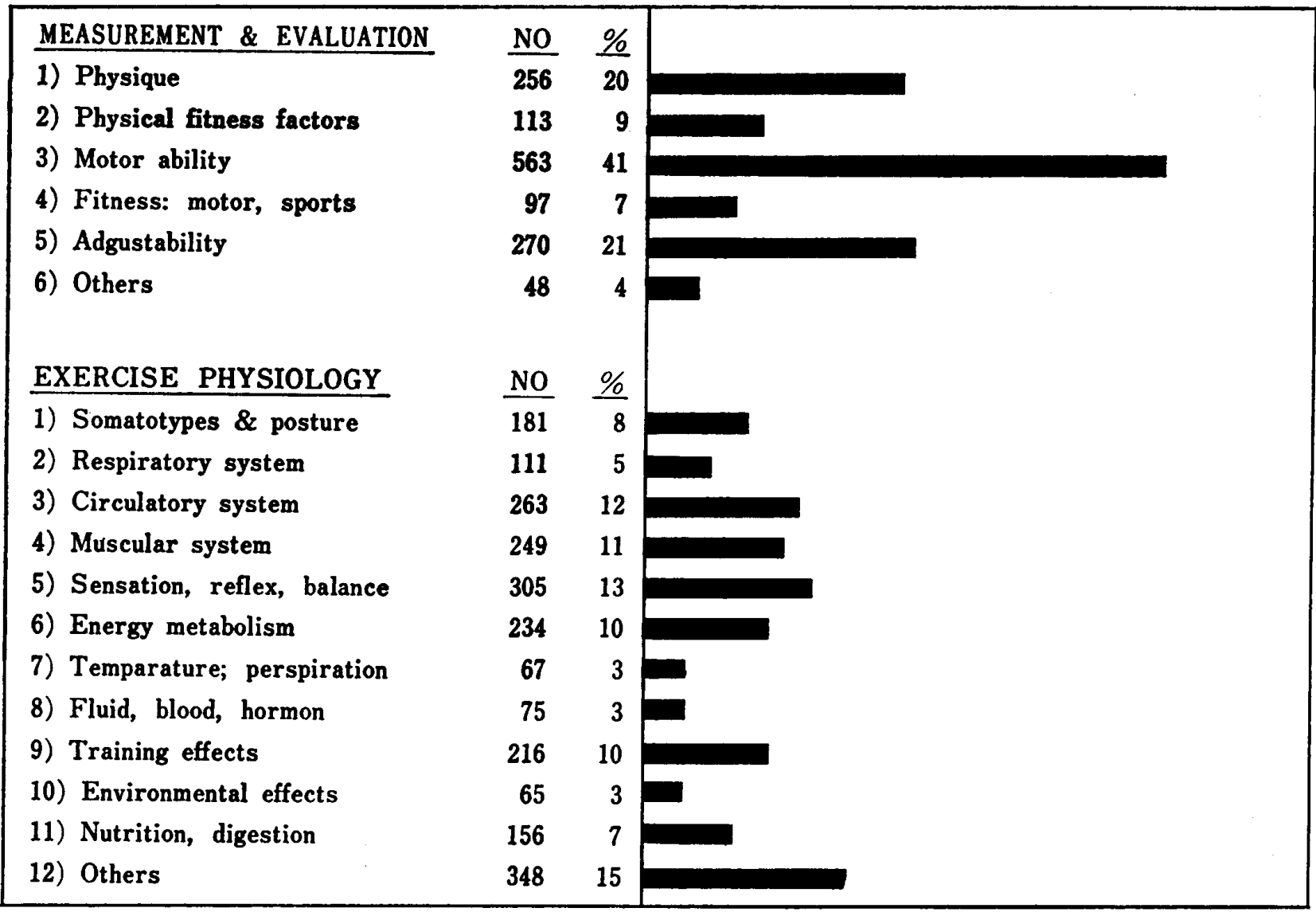

Fig. 10 Numbers and Ratios of Oral Reports Presented at the Annual Conventions : 1950 1974 (JSPE)

\section{Future Tasks to be Fulfilled}

A criticism to the effect that the research products published and introduced in the field of physical education are liable to be not practical for the actual situations especially in teaching, coaching and adult fitness training programs demanded very much today. This criticism, in a sense, is true so far and more individualized and clinical sudies must be carried out by the members of the society in future so that we succeed in establishing a firm base for the field of our profession comparable and respectful to other academic fields.

Natural sciences and their research works should be emphasised more and combined with those of human sciences for the purpose of integrating the works into a real human being in action on the physical activity as the main media all through his entire life. It is rather a favorable inclination to observe the fact that more full papers are printed in the professional periodicals than those orally presented in physiology on one hand, and it is also a negative trend that far less full papers are printed in the division of methodology than those of orally reported on the other hand. Other research divisions equal these numbers. (Figure 11)

Terms and definitions of our fields should be re-examined so that they can be utilized and dissemininated in other academic areas, and the foundational and core sciences must 
PRINTED REPORTS ORAL REPORTS

\begin{tabular}{|c|c|}
\hline PHILOSOPHY & PHILOSOPHY \\
\hline HISTORY & HISTORY \\
\hline SOCIOLOGY & SOCIOLOGY \\
\hline PSYCHOLOGY & PSYCHOLOGY \\
\hline \multirow{2}{*}{ PHYSIOLOGY } & PHYSIOLOGY \\
\hline & KINESIOLOGY \\
\hline KINESIOLOGY & HEALTH ED. \\
\hline HEALTH ED. & $\begin{array}{l}\text { MEASUREMENT } \\
\text { AND } \\
\text { EVALUATION }\end{array}$ \\
\hline $\begin{array}{l}\text { MEASUREMENT } \\
\text { AND } \\
\text { EVALUATION }\end{array}$ & \multirow{2}{*}{$\begin{array}{c}\text { TEACHING } \\
\text { METHODOLOGY }\end{array}$} \\
\hline $\begin{array}{c}\text { TEACHING } \\
\text { METHODOLOGY }\end{array}$ & \\
\hline ADMINISTRAT & ADMINISTRA. \\
\hline \multirow{2}{*}{$\begin{array}{l}\text { GROWTH \& } \\
\text { DEVELOPMENT }\end{array}$} & GROWTH-DEV. \\
\hline & OTHERS \\
\hline
\end{tabular}

Fig. 11 Ratio Between the Numbers of Oral Reports and Those Printed as the Articles in Full Paper. (1950 1974) be indicated so that we may be able to speak and disscuss the same matter together regardless of the differences in our main interests of research areas.

\section{Summary}

The major research trends viewed from the oral reports presented at the annual conventions during past 25 years in Japanse Society of Physical Education were sought in conjunction with the size of the membership of the society.

Approximately a half of the 4,000 members rather regularly presented their reports of studies, while another half depended it upon another half. Among 11 research divisions of the society, more full papers were publihsed in the periodicals than those orally presented in case of the division of physiology, whereas far less published than the oral reports in case of teaching methodology.

The total number of the oral reports paralleled to the increase of the membership up to 1968, but it decreased since then perhaps due to other opened possibilities to present their reports anew in other professional societies in natural sciences related to physical activity and its effects upon human being.

（本論文は1978年 4 月 8日 AAHPER 第93回大会飞扎いて本学会との交流計画の一部として発表されたもの である.)

\section{Bibliography}

1) Hibino, S. "The Research Products and Future Tasks of Physical Education," Ditto, 27-12:834 -47, Tokyo, 1977.

2) Suetochi, H. et al, "The Research Products and Future Tasks of Physical Education-the Special Issue," Journal of Health, Physical Education and Recreation, 25-12:780-841, Physical Education Science Publishing Co. Ltd., Tokyo, 1975.

3) Suetoshi, H. "Recent Trends in Research on Physical Education in Japan" Japanese Journal of Physical Education, 21-6:306-13, Japanese Society of Physical Education, Tokyo, 1977. 